Éva Péteri

\title{
William Holman Hunt
}

\section{'England's Greatest Religious Artist'}

As a result of his devotion to religious art and the immense popularity of some of his religious paintings by the end of the 19th century, William Holman Hunt came to be regarded as "England's greatest religious artist." ${ }^{1}$ And though he was often seen as taking sides in sectarian debates, a closer look at his religious pictures reveal a surprising impartiality.

In his youthful years he was, as he described himself, "a contemptuous unbeliever in any spiritual principles," thus the accusations that his early paintings manifested Tractarian sympathies were unjust and unfounded. ${ }^{3}$ In the 1850s, however, Hunt became a firm believer, which meant a kind of turning point in his art. From that time on he resolved on the "single-minded application of [his] art to the service of Christ" and decided always to remain the "pictorial chronicler of Christianity." $\mathrm{He}$ thus became the embodiment of the Ruskinian ideal described in the first volume of Modern Painters, according to which a painter's vocation was like that of a priest, whose appointed mission was "to express and explain every divine truth which can be gathered out of God's

1 Christopher Wood, The Pre-Raphaelites (London: Wiedenfeld and Nicolson, 1981) p. 106.

${ }^{2}$ George P. Landow, William Holman Hunt and Typological Symbolism. (New Haven and London: Yale University Press, 1979) p. 6.

${ }^{3}$ For more on Hunt's alleged Tractarianism see: 'William Holman Hunt's Early Work and the High Church Movement' The AnaChronisT, 1996.

${ }^{4}$ W. H. Hunt, 'Pre-Raphaelitism and the Pre-Raphaelite Brotherhood' in John Dixon Hunt, Pre. Raphaelite Imagination (Routledge and Kegan Paul, 1968) p. 2.

5 Francis Bickley, The Pre-Raphaelite Comedy (London: Constable and Co. Ltd., 1932) p. 241. 
revelation." ${ }^{6}$ The first picture conceived in this newly found devotion was The Light of the World (1853), an image Hunt "painted with what [he] thought ... to be a divine command, and not simply as a good subject."

\section{'PAPISTICAL PHANTASY' \\ OR 'ICON OF PROTESTANTISM'?: \\ THE LIGHT OF THE WORLD}

Despite Hunt's claims for originality and the fact that he was inspired solely by the text of the Bible there is a stunningly similar 19th century predecessor of The Light of the World. The similitude was spotted by Elisabeth Siddal when she first saw The Light of the World in Hunt's studio. David Larg gives an account of how the startled Miss Siddal called Hunt's attention to it:

... she observed that it was like a very similar picture she had just seen in a Catholic print shop. Yes, 'night, lantern, crown, orchard, overgrown door and all.' At once Hunt set out to look for the shop in Covent Garden where she said this picture was. Sure enough it was there. But it was a 'very poor lackadaisical German figure of Christ - knocking at a meaningless door:' and Hunt returned much relieved, saying that Miss Siddal had a vivid imagination. ${ }^{8}$

But it seems that not only Elisabeth Siddal had such a 'vivid imagination.' The similarity of the two pictures were observed by many others too, so finally Ruskin, who enthusiastically praised The Light of the World in the third volume of Modern Painters, ' felt obliged to defend Hunt against charges of plagiarism admitting at the same time the existence of a pictorial predecessor. So he added an Appendix to the volume, in which he wrote:

6 John Ruskin, Modern Painters (London: J.M. Dent and Sons Ltd., 1923) vol. 1, p. 59.

Letter to William Bell Scott, 19th Aug. 1883, quoted in The Pre-Raphaelites, ed. by the Tate Gallery. (London: Penguin Books, 1984) p. 117.

"David Larg, Trial by Virgins (London: Gowans and Gray Ltd., 1923) p. 146.

9 "...in Hunt's great poetical picture of the Light of the World, the whole thought and arrangement of the picture being imaginative, the several details of it are wrought with simple portraiture; the ivy, the jewels, the creeping plants, and the moonlight being calmly studied or remembered from the things themselves." (p. 39.) "Hunt's Light of the World is, I believe, the most perfect instance of expressional purpose with technical power, which the world has yet produced." (p. 29.) 
I have so often spoken, in the preceding pages of Holman Hunt's picture of the Light of the World, that I may as well ... glance at the envious charges against it of being plagiarised from a German print. It is indeed true that there was a painting of the subject before; and there were, of course, no paintings of the Nativity before Raphael's time, nor of the Last Supper before Leonardo's, else those masters could have laid no claim to originality. But what was still more singular (the verse to be illustrated being, "Behold, I stand at the door, and knock"), the principal figure in the antecedent picture was knocking at a door, knocked with its right hand, and had its face turned to the spectator! Nay, it was even robed in a long robe, down to its feet. All these circumstances were the same in Mr. Hunt's picture; and as the chances evidently were a hundred to one that if he had not been helped to the ideas by the German artist, he would have represented the figure as not knocking at any door, as turning its back to the spectator, and as dressed in a short robe, the plagiarism was considered as demonstrated. ${ }^{10}$

As L. Robinson pointed out in his lecture Pre-Raphaelites and the German Connection, ${ }^{11}$ the German print in question was a reproduction of one of the Nazarene painters', Philip Veit's works. No wonder, therefore, that both Ruskin and Hunt, who were equally hostile to the Nazarenes, tried to dissociate The Light of the World from the print. Whether Veit's image made an unconscious impression on Hunt's mind, which was evoked while he was reading the Bible, or the two artists came to the same idea accidentally is impossible to decide. Nevertheless, Hunt always regarded The Light of the World as the manifestation of his own, personal experience of divine revelation, so much so that only in the case of this picture did he think self-expression more important than public interest. As he later referred to it:

I may say that any occult meaning in the details of my design was not based upon ecclesiastical or archaic symbolism, but derived from obvious reflectiveness. My types were of natural figures such as language has originally employed to express transcendental ideas, and they were used by me with no confidence that they would interest any other mind than my own. ${ }^{12}$

\footnotetext{
${ }^{10}$ Ruskin, Modern Painters, vol. 3, pp. 324-5.

11 Delivered at the Bar Convent Museum in York on 20th April, 1991.

${ }^{12}$ John Dixon Hunt, Pre.Raphaelite Imagination (Routledge and Kegan Paul, 1968) pp. 137-8.
} 
Hunt's resolution not to rely on the legacy of earlier biblical presentations and the highly personal and imaginative character of the work meant that, when first exhibited in 1854, the picture proved to be less comprehensible to most of the contemporary spectators than would be thought in view of the picture's later popularity. To guide the mindful audience and reveal the literary source of the painting, a biblical quotation was inscribed on the frame, citing the Revelation:

Behold I stand at the door and knock: if any man hear my voice, and open the door, I will come to him, and will sup with him, and he with me.

(Rev. 3:20)

Thus the central image was explained: Christ arriving, asking for admittance, asking for acceptance. However, to acquire fuller understanding, to decode the significance of the numerous details incorporated into the scene, one had to be well-versed in the text of the Bible. Himself being quite familiar with the Scriptures by this time, Hunt could create a pictorial complex full of meaningful, inter-related references, each of which contributed to the artist's 'priestly' message. The title itself comes, for example, from the 8th chapter of the Gospel according to St John, where Christ declares himself the light of the world saying: "I am the light of the world: he that followeth me shall not walk in darkness, but shall have the light of life" (John 8:12). Christ gives guidance to man like a lamp does in darkness, as it is said in the Psalms: "Thy word is a lamp unto my feet, and a light upon my path" (Psalms 119:105). Quite untypically of Hunt's usual insistence on presenting things as they might actually have happened and in contrast with his claim of not relying on the conventions of religious art, he depicts Christ as a crowned king, a portrayal based on tradition, which has its source in Jeremiah's prophecy:

Behold, the days come, saith the Lord, that I will raise unto David a righteous Branch, and a King shall reign and prosper, and shall execute judgement and justice in the earth.

(Jer. 23:5)

The image of the neglected orchard recalls how the garden of Eden was entrusted to man in Genesis 2:15 "And the Lord God took the man, and put him into the garden of Eden to dress it and to keep it"), and then, despite the divine charge, abandoned and neglected, as the rank briar refers to it in the painting just as it does in the Bible ("And it shall come to pass in that day, that every place shall be, where there were a thousand vines at a thousand silverlings, it shall even be for briars and thorns." [Is. 7:23]). The picture as a whole also recalls the parable of the 
wise and foolish virgins (Matt. 25:1-13) in the sense that it warns of constant vigilance by presenting man's unpreparedness at the time of Christ's arrival during the night.

These symbolic references were comprehensible to a select audience of regular church-goers and conscientious readers of the Bible. The number of this receptive, understanding audience, however, did not satisfy the aesthetic sense and educating spirit of Ruskin. His genuine enthusiasm for the painting and his desire to gain wider public appreciation to such a valuable work of art impelled him to write an elaborate interpretation of the painting for The Times, in which he tried to unveil its biblical references. As Timothy Hilton points out, ${ }^{13}$ Ruskin concentrated on the signs of human ignorance, on the devastation caused by neglect, and not so much on the hope of salvation brought by Christ. ${ }^{14}$ Ruskin's Evangelical upbringing, which taught him always to be conscious of man's fallibility and inclination to sin was probably one reason behind his rather pessimistic view, but it was also caused by the fact that some of the more positive references consciously employed by the painter were so complex and so individual that they were unattainable even by Ruskin's expertise. Though originally Hunt wished "the picture to be left without any explanation," 15 he finally, but only in 1865, resigned to publishing a pamphlet, An Apology for the Symbolism Introduced into the Picture called The Light of the World with a detailed description of the painting. In this essay Hunt reveals the meaning of two important, though seemingly insignificant, elements incorporated into his work.

Both the lamp held in Christ's hand and the clasp which fastens his robe were contrived by the painter, and show his constant striving to provide every single detail of his pictures with symbolic meaning. The lantern was painted after a model designed by Hunt himself and constructed strictly according to his special requirements. A drawing of it reveals that it had seven sides each of which was formed as a divided window with differently shaped apertures above them. According to Hunt they were to represent the seven churches mentioned in Revelation (1:19-20), which appear there as the seven golden candlesticks. The fact that in Hunt's image Christ appears delivering the light of life as shining through

\footnotetext{
${ }^{13}$ Timothy Hilton, The Pre-Raphaelites (London: Thames and Hudson, 1993) p. 92.

${ }^{14}$ The door of the human soul, for example, is described by Ruskin as "fast barred, its bars and nails are rusty; it is knitted and bound to its stanchions by creeping tendrils of ivy, showing that it has never been opened. A bat hovers above it; its threshold is overgrown with brambles, nettles, and fruitless corn." Quoted in Hilton, The Pre-Raphaelites p. 92.

${ }^{15}$ Quted in The Pre-Raphaelites p. 119.
} 
a lantern with the emblems of seven churches was regarded as the painter's belief in the existence of more than one true church. It was seen later by the Anglican clergy as such a serious offence that it caused anxiety even in 1908 when the picture was given to Keble College and its officials felt obliged to object to the painting on this ground. ${ }^{16}$

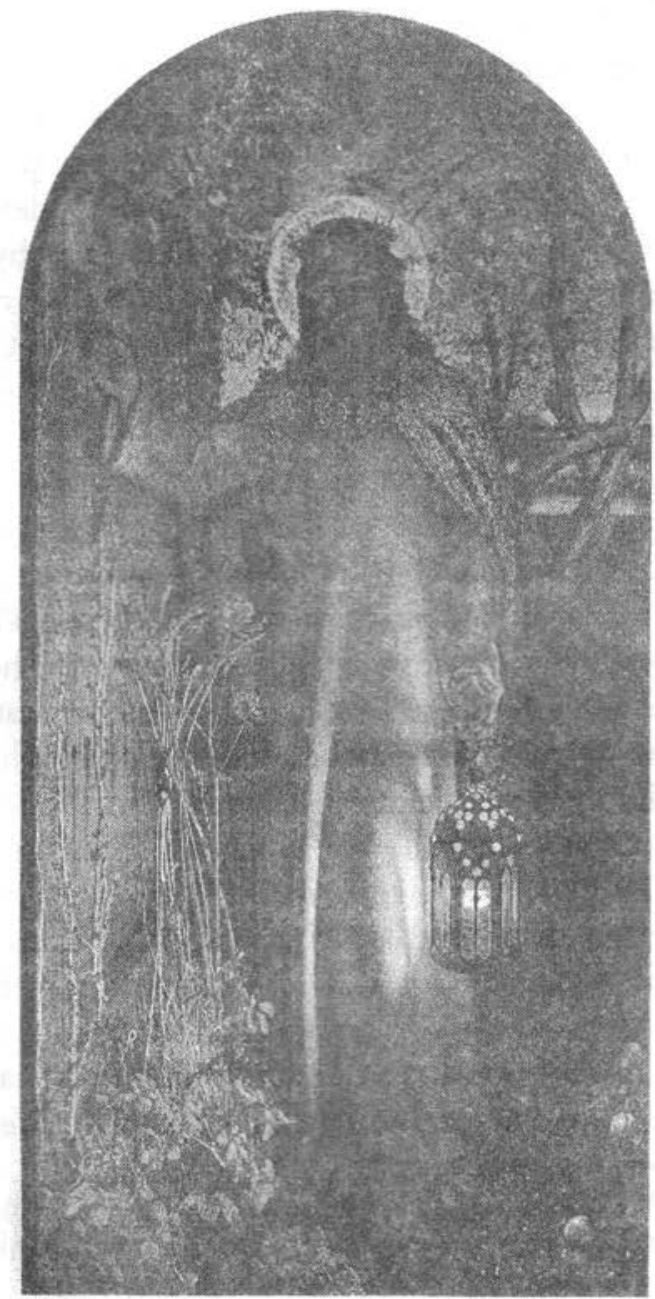

${ }^{16}$ The Pre-Raphaelites p. 120. 
Hunt's tolerant religious approach is reflected in the symbolism of the clasp or breast-plate too. It consists of three parts, each about the same size but with a different shape. On the left the circular part refers to the heathen priesthoods, since many pagan priests actually bore such symbols. ${ }^{17}$ The middle section is cross-shaped, symbolising the Christian congregations by recalling Christ's crucifixion. The red precious stones, with which it is encrusted, refer to the wounds he suffered, and they correspond with the stigmata shown in the painting on Christ's hands. The third, rectangular clasp is an Israelitish symbol, it has the shape and lay-out of the breast-plate of judgement made for Aaron as described in Exodus 28:15-24. Although, as the colours of the painting reveal, they are not shown by Hunt in the enlisted biblical order, their arrangement and number - four rows with three stones in each - are precise. It seems that since the types of these stones did not seem to have symbolic reference in the Old Testament, the otherwise always painstakingly accurate Hunt concentrated only on the presentation of the correct number of the stones, since they were symbolically important bearing the names of the children of Israel and referring to the twelve chosen tribes. This rectangular plate may be identical with the breast-plate of judgement containing the mystic Urim and Thummin (Exodus 28:29-30), with the help of which the will of God could be made known to the children of Israel. This tripartite breast-plate, the creation of Hunt's fertile mind, combining the symbols of heathens, Christians, and Israelites represents the same message as the seven-sided lantern; that the light of the world is accessible to all regardless of denomination. This early and very conscious sign of Hunt's tolerance and open-mindedness in religious matters is often neglected, though such flexibility was not at all in conformity with current popular feeling. No wonder, therefore, that Hunt did not reveal the meaning of these symbolic objects of the painting till 1865 . Even then it was a rare thing to hold such tolerant views, but by that time the painting had gained so much in popularity that basically nothing could damage its public reputation.

When first exhibited in 1854, the picture did not bring immediate success, despite the fact that the Victorian spectators had not the slightest idea about its more complicated symbols and the liberal view they reflected. The Art Journal, for example, disapproved of it for its realisation of the ideal, writing that "The knocking at the door of the soul is a spiritual figure of such exaltation that it must

${ }^{17}$ Referred to by F. G. Stephens in William Holman Hunt and His Work, 1860. Quoted in The PreRaphaelites p. 119. 
lose by any reduction to common forms." ${ }^{18}$ To accept Hunt's ambitious attempt to render a highly imaginative and symbolic image in a truly Pre-Raphaelite manner was, at first, difficult for the public. It must be added, however, that Hunt himself admitted making compromises in this case and deliberately idealising the face of the Saviour because he wanted to add a certain amount of mysticism to the image underlining its revelationary nature. ${ }^{19}$ But the painter's approach was strongly criticised by Thomas Carlyle too, who wrote to Hunt in a letter:

Do you ever suppose that Jesus walked about bedizened in priestly robes and a crown, and with jewels on His breast, and a guilt aureole round His head? ... Don't you see that you are helping to make people believe what you know to be false, what you don't believe yourself? ${ }^{20}$

In Carlyle's view Hunt offended against what is called by Houghton Victorian earnestness ${ }^{21}$ by presenting something that was historically obviously not true. $\mathrm{He}$ disapproved of Christ being shown as a "feeble, pretty priest, decked out in bejewelled finery," and called The Light of the World a "papistical phantasy." $22 \mathrm{He}$ detected a sense of Catholic sympathy, and the painting was quickly rejected. And Carlyle, in a sense, was obviously right. Christian mysticism and inspired, enthusiastic visions belonged more to the Catholic tradition of worship, and it is no wonder, therefore, that this painting was again purchased by the Tractarian Thomas Combe.

Strangely enough, by the 1860 s The Light of the World had become a celebrated icon of Victorian Protestantism. ${ }^{23}$ The Victorians came to see it as it was seen by Bickley, who wrote in 1923 that:

It is ... the religious picture of the Protestant. Hunt was, except for his talent, a typical Protestant Englishman of his time. He put all himself into that work, depicting a Saviour solemn and humane, whose aureole

\footnotetext{
${ }^{18}$ Quoted in The Pre-Raphaelites p. 118.

${ }^{19}$ As Hunt wrote in a letter to J.L. Tupper on 20 th June, 1878, he "... felt very determined to make the figure mystic in aspect." Quoted in The Pre-Raphaelites p. 119.

${ }^{20}$ Bell, Quentin: A New and Noble School, the Pre-Raphaelites (London: MacDonald, 1982) p. 77.

${ }^{21}$ Walter E. Houghton, The Victorian Frame of Mind 1830.1870 (London: Oxford University Press, 1957) pp. 220-22.

${ }^{22}$ Kenneth Bendiner, An Introduction to Victorian Painting (Yale University Press, 1985) pp. 67, 69.

${ }^{23}$ Cf. David Crowley, An Introduction to Victorian Style (London: Apple Press, 1990) p. 70.
} 
signified his holiness but hinted at no Popish mysteries. The picture struck an answering and lingering chord in a million English breasts. ${ }^{24}$

Though in view of his religious tolerance it seems to be questionable whether Hunt was a typical Protestant of his time, it is undeniably true that, in the end, the painting became immensely popular, not least because of its concentration on the most important problem occupying the public religious mind in the 1860s.

By that time the detestation of Catholicism and fear of Catholic propaganda was pushed into the background by a far more harassing problem: the spreading of scepticism, and even the loss of Christian belief altogether. A certain amount of mysticism thus became more easily accepted as long as it served conversion or helped to preserve faith. Hunt's picture warned Christians never to abandon their religious duties, never to discard the love and service they owe to their Saviour. This image, which showed Christ appearing to the living in a very realistic setting could give a much needed reassurance to many of its spectators, and made the work a desirable piece for reproduction, to be hung in schoolrooms and family parlours. Though J. Steegman feels that this "... timorous, self-pitying Christ could in no circumstances ... illuminate or save the world, ${ }^{25}$ his view was definitely not shared by the crowds who wanted to possess a copy. However, Steegman's claim that the image has an unmistakable sentimental appeal, an early symptom which "... foreshadows the decline of the early, intense, pure PreRaphaelitism into a sentimental-romantic otherworldliness" ${ }^{26}$ can be easily agreed with. Giving way to idealisation and irrational elements in this picture, Hunt moved away from his earlier principles, but only to return to pure realistic presentation in his next work.

\footnotetext{
${ }^{24}$ Bickley p. 241.

${ }^{25}$ John Steegman, Consort of Taste (1830-1870) (London: Sidwick and Jackson Ltd, 1950) p. 262.

${ }^{26}$ Steegman p. 263.
} 


\section{not}

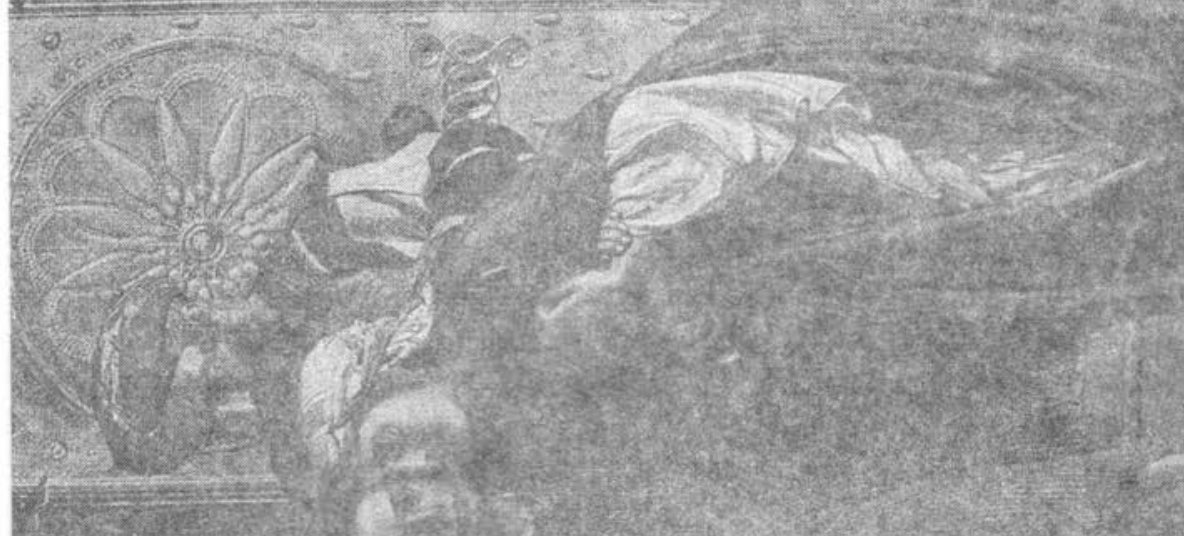

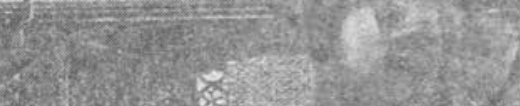

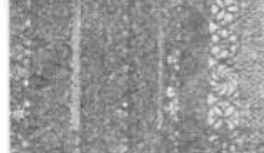

+4.

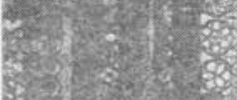

45. 50 is

(5e)

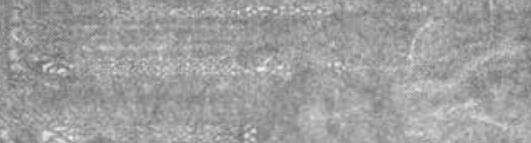

$$
\text { (3) }
$$

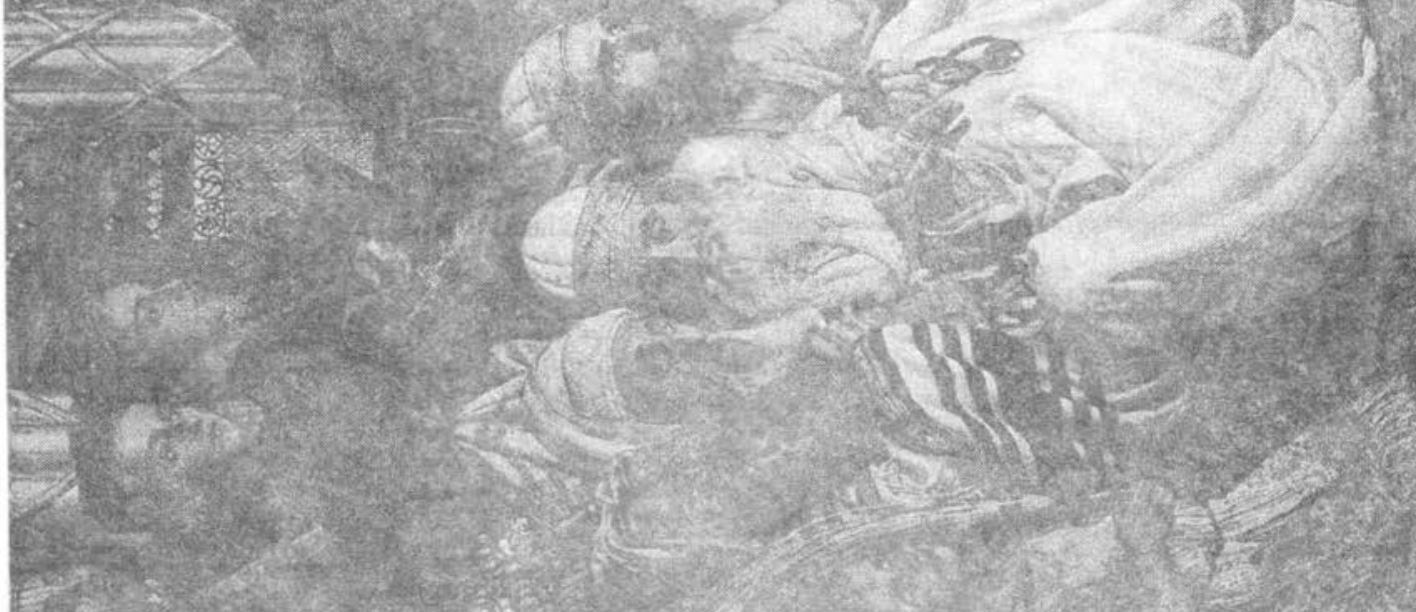


TYPOLOGICAL SYMBOLISM: THE FINDING

In The Finding of the Saviour in the Temple Hunt attempted to achieve an overall accuracy: not just realism in presentation, but also a strict adherence to historical and biblical facts. Elements of mystic nature were completely excluded.

By 1854 Hunt became convinced that in order to present biblical scenes truthfully he had to go to the Holy Land and acquire a first-hand knowledge of the place and the people he intended to paint. His conception was part of a more general Victorian trend, and he was not the first and only painter in such a pursuit. Sir David Wilkie travelled to the Middle East in 1840, and David Roberts and John Frederick Lewis followed his example in 1842. Hunt finally left England in January 1854. He started working on The Finding in the same year, but it took 16 years till he could regard it as completed.

Since reading Ruskin's Modern Painters in 1847 Hunt had wanted to achieve such complexity in religious pictorial presentation as is shown by Ruskin in 'Tintoret's Annunciation. With The Finding Hunt, at last, could achieve his aim. Breaking away from the mystic nature of The Light of the World he could here successfully present matters of the spiritual world in a highly and purely realistic manner by making the most of prefigurative or typological symbolism. Highlighting the change in Hunt's artistic approach Landow points out that while The Light of the World

recorded a vision that took form in [Hunt's] own mind, thus creating a pictorial emblem of that spiritual experience, ... the typological works ... gained access to the world of the spirit by means of symbols - types which partake simultaneously of the material and the spiritual, the temporal and the eternal. ${ }^{27}$

Though bound by the natural limitations of visual art and obviously able to depict only a single moment of the Saviour's life in one painting, Hunt extended the scope of his image by means of integrated prefigurative symbols: important past and future events are referred to, while all are focusing on the main incident actually shown.

The Finding basically concentrates on the clash between the old and new religious laws: Christ is shown as the bearer of new faith facing the stiff opposition of the Pharisees, the representatives of the old one. The main theme of

${ }^{27}$ Landow p. 125. 
rejection - the rejection of Christ and the new law he stands for - is underlined by parallel background scenes. A church-building process is shown on the right; masons are giving the finishing touches to the keystone while others are considering it and are about to reject it. Here Hunt applies a conventional type taken from the Bible itself, where Christ is referred to by the Apostles as the keystone of the church and the congregation (Matt. 21:42, 1Peter 2:5-6). Behind this scene, in the far distance, the Mount of Olives can be seen, the place of Christ's betrayal and consequent arrest. In the back of the Jewish temple a lamb is shown as being taken away for baptismal sacrifice, an obvious reference to Christ's own death.

The chief rejecters, the Rabbis sit in a semicircle around Christ, their discussion with the young boy brought to an end by the arrival of the relieved parents. The doctors are clearly not convinced, not yielding to Christ's arguments. Again, as is usual with Hunt, nothing is accidental in the presentation. In the case of this painting the indispensable detailed explanation is provided by $F$. G. Stephens, whose pamphlet was vetted by Hunt himself. ${ }^{28}$ Stephen claims that each of the Rabbis stands for a certain aspect of the corruption of the old law, and thus together they are showing the unworthiness of their faith. The chief of them, a blind old man sitting on the left and clutching the Torah displays blind insistence upon the old, lapsed doctrine. His spiritual blindness is contrasted by the other blind figure of the picture, the beggar, who is sitting at the gate of the temple on the right side of the painting, and whose sight is to be restored by Christ for believing in his teaching (John 9:1-11). The other grey-bearded Rabbi, sitting next to the chief and holding a phylactery-box, represents the ever-faithful member of any establishment, who is never troubled by new ideas. His neighbour displays just the contrary quality; he is argumentative and passionate, but his eagerness is used only to prove his own point. The fourth Rabbi, wearing an unusually broad phylactery-box on his forehead, is an intellectual type, whose expression shows extreme self-satisfaction and self-centeredness, while the fifth is concerned only about his physical well-being. The next in the row, inquiringly leaning forward to catch a glimpse of the persons who interrupted the conversation, represents the envious, curious type, while the last one displays repugnant sensuality. The Torah, which contains the five books of Moses, is itself the symbol of the old law, and the young boys surrounding it display the idolatrous love with which it is adored; most of them are musicians, one of whom

${ }^{28}$ Stephens' pamphlet is quoted in Landow pp. 87.92, and in The Pre-Raphaelites pp. 159-60. 
is actually shown kissing the Torah, while another boy is employed to chase the flies away from this precious icon.

As opposed to the group of the Israelites inside the temple the Holy Family stand at its golden gate. Corresponding to the incident shown in the picture, a part of Malachi's prophecy is inscribed in Latin and Hebrew on the gate saying: "And the Lord, whom ye seek, shall suddenly come to the temple" (Mal. 3:1). Malachi's prophecy can be found right at the end of the Old Testament, where through Malachi God complains about the ingratitude of Israel (Mal. 1), and the profanation of the covenant by her priests (Mal. 2), and He promises to send His messenger to renew His alliance with the people (Mal. 3). With Christ's appearance in the temple the prophecy is fulfilled, though it seems that nobody realises it except the young Christ himself.

He seems to be absorbed in distant thoughts, paying attention neither to the Rabbis and the discussion he had with them, nor to his mother who approaches him with great relief in finally finding her son after three days of search. As Landow suggests ${ }^{29}$ the moment shown in the painting is actually Christ's sudden realisation of his appointed mission, an instant in which he may have a foreboding of his fate and his future work. Tiny, but important details can support this argument. One of them is that Christ is shown tightening his belt, which evokes the biblical descriptions of how Israelites were expected to "gird their loins" before going to battle or when preparing for hard work (Ex. 12:11, 2Kings 4:29, 9:1), and on the basis of Jeremiah (13:11) it can also refer to the reinforced bond between God and His people. The cross on Christ's belt, referring to his sacrificial death, is another sign of this renewed alliance. Another point to support Landow's idea is Hunt's choice of the quotations inscribed on the frame of the painting. He decided to omit certain lines of the section relating the story in order to direct the spectator's attention onto the aspects he found important in connection with his work. The biblical description of the scene can be found in the Gospel of Luke, and goes as follows:

And when they found him not they turned back again to Jerusalem, seeking him.

And it came to pass that after three days they found him in the temple, sitting in the midst of the doctors, both hearing them, and asking them questions.

${ }^{29}$ Landow p. 102. 
ÉVA PÉTERI

Here Hunt omitted the next verse which says: "And all that heard him were astonished at his understanding and answers" (2:47). Then he continued quoting:

And when they saw him, they were amazed: and his mother said unto him, Son, why hast thou thus dealt with us? behold, thy father and I have sought thee sorrowing.

And he said unto them, How is that ye sought me? wist ye not, that

I must be about my Father's business?

The next part was also left out: "And they understood not the saying which he spake unto them" (2:59). Then the story as well as the quote is concluded: "And he went down with them, and came to Nazareth, and was subject unto them: but his mother kept all these sayings in her heart" (2:51).

Probably by reason of the fact that this event is the only one of the youthful years of the Saviour which is mentioned in the New Testament, it has always been a popular subject in religious painting. Traditionally, however, the emphasis was laid on Christ's teaching the doctors, while Mary and Joseph were treated as secondary characters shown perhaps at a far side or in the background of the picture. ${ }^{30}$ In Hunt's painting just the contrary happens. The theological debate is pushed to the background, overshadowed by the family's reunion. In certain cases painters depicted the scene with Mary in the centre. ${ }^{31}$ These works were conceived in the tradition which regarded the finding of the Saviour in the temple as one of Mary's seven joys as contrasted to the loss of the child in Jerusalem, which was considered as one of the Virgin's seven sorrows. Hunt's approach is even more striking when compared to this tradition. He presents the episode not at all as if it was a happy moment for the mother. Here Mary encounters a painful experience, a bitter feeling for being rejected for the first time by her son, an affliction which was on her mind and laid heavy on her heart for long. The theme of rejection is repeated here, though with a different meaning.

This sudden and quite ruthless denial of the mother by the young Christ is the sign of his realisation of his mission. An ignorant child has just turned into a man perceiving and taking on his duties and responsibilities. The painting thus presents an important Victorian concept according to which work was a supreme virtue, the condition of common progress and self-improvement. "Every one who breathes, high and low, educated and ignorant, young and old, man and woman,

\footnotetext{
${ }^{30}$ See, for example, Bernardino Luini's Christ among the Doctors, or Giotto's Christ among the Doctors.

${ }^{31}$ See, for example, Claudio Coello's The Child Jesus at the Gate of the Temple.
} 
has a mission, has a work," wrote Cardinal Newman. ${ }^{32}$ It was man's duty as well as privilege to find his mission, and the critic of The Athenaeum was glad to see that "the idea of duty predominates all" in the painting. "Blessed is the man who has found his work ...," "let him ask no other blessedness" ${ }^{34}$ wrote Carlyle, and The Finding visualises the exact moment when Christ finds his work, the hardest and noblest ever delivered, as experienced in a sudden self-recognition, a divine message dressed in human form. For this quality of the painting Landow regards it as a Protestant version of the traditional Annunciation theme, ${ }^{35}$ which eliminates the mystic immaculate conception and delivers the divine message to the conscious intellect of the youthful Christ. Accordingly, Mary appears as a simple earthly mother, puzzled and not comprehending her son's words and behaviour. The elected divine role of Mary is thus abolished, and the traditional Catholic adoration of her is denied. Mary's repudiation both on the concrete and on the abstract level is seen by Landow as Hunt's rejection of Roman Catholic Mariolatry. ${ }^{36}$

To regard the painting as a unique Annunciation can again be justified by small details incorporated in the crowded scene. The doves, for example, the indispensable attributes of the Annunciation scenes are present, traditionally symbolising the Holy Ghost, God acting spiritually. They enter the church together with Christ, enhancing the idea that a divine message is delivered to the Israelites by the appearance of Christ. As Christ the messenger is rejected by the Pharisees, so are the doves chased out of the temple by a Jewish girl in the background. Also in the background, on the left-hand side, a man is shown lighting a lamp, which may correspond to Christ's rejected message on the basis of the Gospel of St John: "the light shineth in darkness; and the darkness comprehended it not" (1:5), but it may also underline Christ's own illumination.

In such complex symbols as these Hunt could find the proper means to work with. Employing them he could spiritualise concrete facts or details, deliver moral messages, and, in addition, calculate that many of the Victorians would find them relatively easy to understand, since they were widely used in sermons,

\footnotetext{
${ }^{32}$ Quoted in Debra N. Mancoff, The Return of King Arthur: The Legend through Victorian Eyes (New York: Harry N. Abrams, Inc., Publishers, 1995) p. 56.

${ }^{33}$ Bendiner p. 66.

${ }^{34}$ Houghton pp. 243-44.

${ }^{35}$ Landow p. 102.

${ }^{36}$ Landow p. 103
} 
especially by the Evangelicals. ${ }^{37}$ And, though it is very difficult to estimate how much an average contemporary spectator could really comprehend of the picture's abundant symbolism, the outstanding public success the painting enjoyed immediately after its first display suggests that the method needed for basic understanding was familiar to most of them. In a way The Finding is similar to the so called Victorian 'problem pictures ${ }^{38}$ which invite the spectator to detect clues that can help a fuller understanding, thus to "read the painting" like a book. The basic difference between a problem picture and Hunt's The Finding or the later The Shadow of Death is that while the former relies almost exclusively on visual hints and requires only an attentive examination of the painting, the decoding of Hunt's works presupposes literary, mostly biblical erudition, since they employ symbols and not just visual elements as keys to understanding.

A. P. Oppe attributes the picture's popularity to what he sees as the conventionality of the work. As he says:

[people] flocked in thousands to see the picture which was certainly England's masterpiece and perhaps the world's, not only because it had taken longest to paint and had fetched the largest price, but also because it contained the greatest mass of detail and the brightest colours, with no novelty of conception to puzzle the mind and no disconcerting visual feature of atmosphere or design. ${ }^{39}$

$\mathrm{He}$ adds that the painting exhibits "precisely the semi-classical convention which the Pre-Raphaelite Brotherhood had originally set out to replace," and that it was "in effect a criticism of the early Christian affectations displayed by Millais in The Carpenter's Shop and, still more, the growing eccentricities of Rossetti." ${ }^{40}$ There is, of course, a difference between the religious sentiment of Millais' and Rossetti's early works and Hunt's reserved moral symbolism. However, they all reflect the same interest in making Christ's life more familiar, trying "to actualise the distant and scarcely conceivable," as J. D. Hunt puts it. ${ }^{41}$ Millais' wish to present a real carpentry with unidealized figures in his Carpenter's Shop and Rossetti's aim to

${ }^{37}$ Landow p. 106.

${ }^{38}$ See, for example, Alfred Rankley's Old Schoolfellows (1854), Robert Braithwaite Martineau's The Last Day in the Old Home (1861), or George Elgar Hicks' Woman's Mission, Companion of Manhood (1863).

${ }^{39}$ G. M. Young, ed., Early Victorian England 1830-1865 (Oxford: Oxford University Press, 1988) p. 170.

${ }^{40}$ Young 171.

${ }^{41}$ John Dixon Hunt p. 26. 
show the scenes of Mary's life in a genuine, historically plausible manner in his The Girlhood of Mary Virgin and Ecce Ancilla Domini served a purpose similar to that of Hunt. In The Finding Christ's presentation as a strong Jewish boy as well as the painstaking effort to provide an authentic setting ${ }^{42}$ was part of a general tendency to convince people about Christ's real, historical existence, at a time when the credibility of the biblical stories was challenged by scientific evidence.

The Finding in this respect, and painting in general, preceded most of the scholarly or literary attempts which tried to present a verisimilar account of the life of Christ. Apart from Strauss' Life of Jesus, which was written in 1835 but published in England in George Eliot's translation only in 1846, there was no such publication till the 1860s, when the writings of Renan, J. R. Seeley, Sir Richard Hanson, Bishop Ellicott, and later F. W. Farrar came out within a short time. And though Strauss' work is regarded as the first startling attempt "to describe Jesus as a human person," endeavour, which failed for being "too theological to be historical." 4

In the sense that The Finding served as a kind of reassurance for the Christian congregations about the validity of their faith, it has a message similar to that of the earlier The Light of the World. The difference, though, is that the imaginative, visionary character of The Light of the World made it less readily accessible to its audience than the more realistic nature of its successor.

\footnotetext{
${ }^{42}$ Apart from travelling to the Holy Land in order to see the place where all these biblical events actually happened, Hunt examined different sources to find the possible architectural features of an early Jewish temple to show Herod's temple in the painting accurately. He studied, for example, the Alhambra Court of the Crystal Palace, and the biblical description of Solomon's temple (2Chron. 3:7, 4:12-13). For further details see Bendiner pp. 73-75.

${ }^{43}$ Owen Chadwick, The Victorian Church (New York: Oxford University Press, 1966) vol. 2, p. 61.

${ }^{44}$ Chadwick 62.
} 


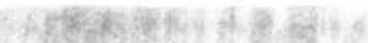

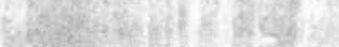

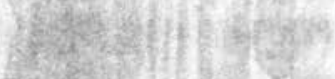

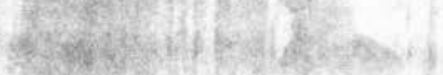

(36)

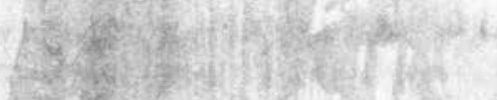

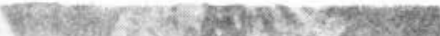

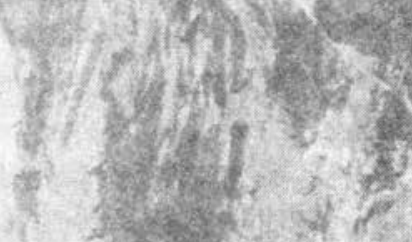

a.

4

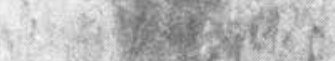

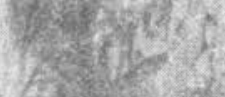

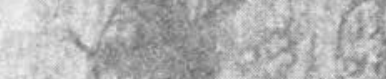

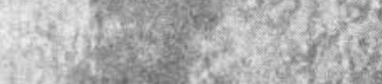

(1)

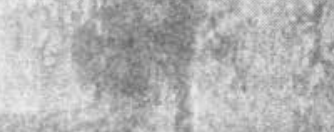

ind

(x)

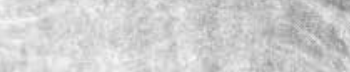

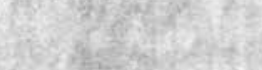

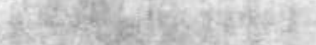

Rex

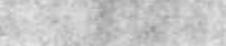

8.8.

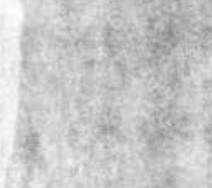

(1)

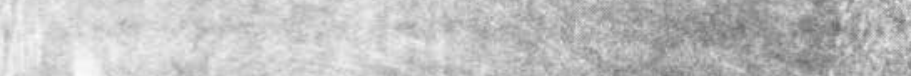

W.

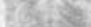

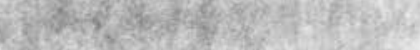

(2)

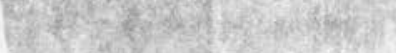

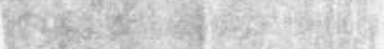

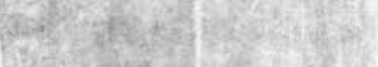

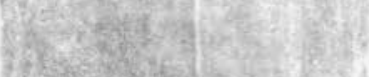

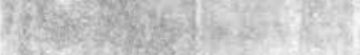

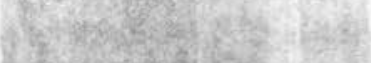

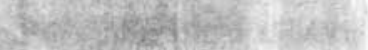

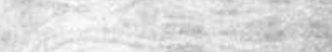

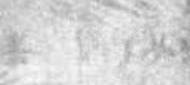

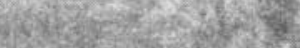

Aris

(2)

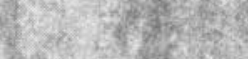

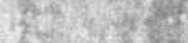

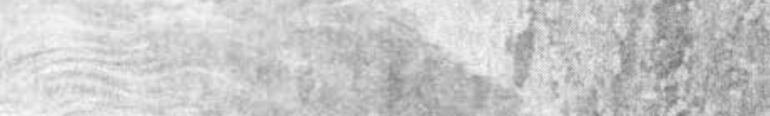
tos 1. (1) $2 x^{2}+3 x+5$
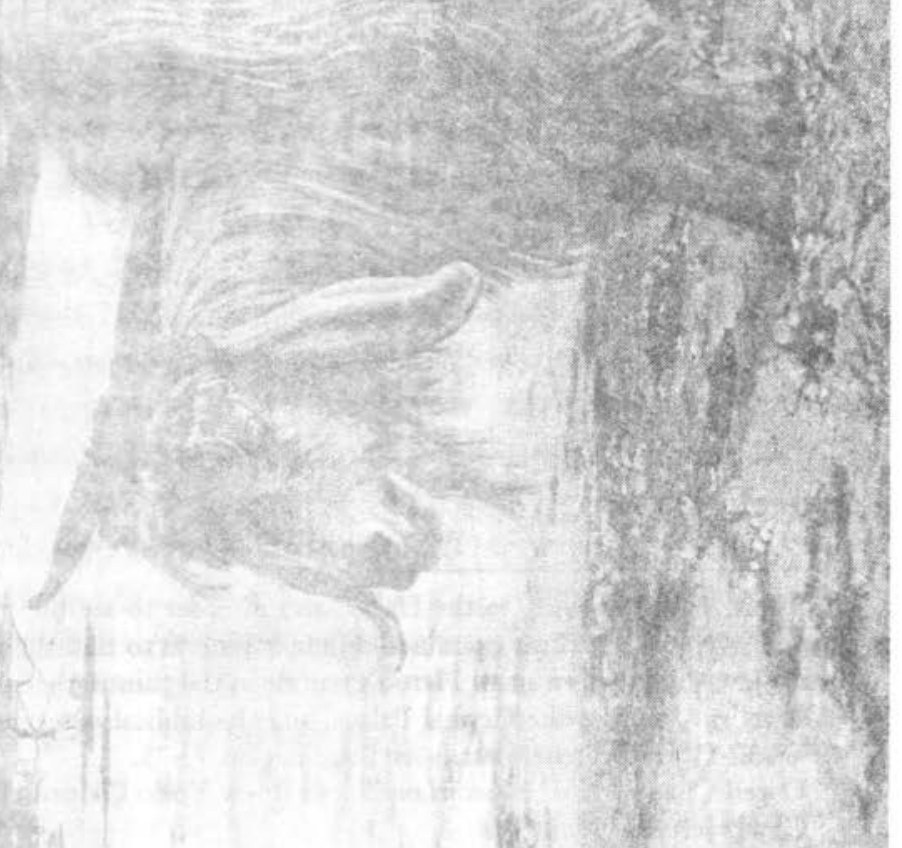

(2)

(4)

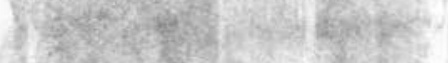

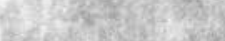

6.0.

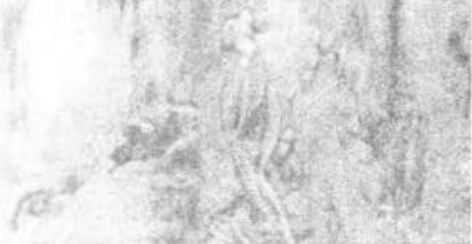




\section{APPALLING ACCURACY: THE SCAPEGOAT}

Though regarded as the most consistent in his artistic principles among the PreRaphaelites, Hunt never quite repeated himself. The famous The Scapegoat which was produced during the intervals when Hunt had difficulties carrying on with his work on The Finding, ${ }^{45}$ presents an unparalleled, most unusual religious image. While making use of the same type of typological symbolism as he applied in The Finding, he here singled out one basic type and made it the core of his conception employing other types only as subordinate ones with complementary functions.

The chosen type is again not new in itself; it is taken from the Old Testamental description of the sacrificial goat, which is the traditional type of the Saviour. The surprising thing is, though, that never before in Hunt was this type used or shown in visual presentation. When he discovered it as a novel subject for a painting Hunt thought of offering it as a theme to Landseer, the celebrated animal painter of the time, the Queen's favourite painter, but finally he decided on the execution himself. Landow sees Landseer's An Offering (1861) presenting a goat bound and laid upon a pile for sacrifice as a successor of Hunt's Scapegoat, ${ }^{46}$ and strangely enough, J. Nicoll finds a possible predecessor to Hunt's work in another of Landseer's paintings, The Challenge, which was first exhibited in $1844 .^{47}$ Though The Challenge is very different in conception from The Scapegoat, not even a religious picture, the scene - a solitary animal in a desolate land with a lake and distant mountains in the background - definitely bears some resemblance to Hunt's.

In other respects, however, Hunt's The Scapegoat has nothing in common with Landseer's popular, often sentimental animal pictures. Landseer masterly exploits the characters of the animals portrayed, often endowing these images with human traits as he does in The Old Shepherd's Chief Mourner (1837), The Monarch of the Glen (1839) or in Dignity and Impudence (1851). As Treuherz describes, Landseer "brings to animal painting the epic and heroic qualities of high art." ${ }^{48}$ Hunt's exhausted, starving goat has neither dignity, nor sentiment. ${ }^{49}$ It

\footnotetext{
${ }^{45}$ Hunt had great difficulties in finding sitters for his painting, since in 1854 it was forbidden for the Jews to work for Christians, and Hunt insisted on employing only semitic models. For further details see The Pre-Raphaelites p. 158.

${ }^{46}$ Landow p. 110.

${ }^{47}$ John Nicoll, The Pre-Raphaelites (Studio Vista, 1970) p. 18.

${ }^{48}$ Julian Treuherz, Victorian Painting (London: Thames and Hudson, 1993) p. 30.
} 
generates neither elevated feelings, nor sweet smiles; it is basically repulsive and unpleasant to look at. This is, of course, a great achievement, since that is exactly the moral 'duty' of the picture: to rouse the benignant spectator by showing him how an innocent creature must suffer for his own iniquities.

The intention was noble and the idea was not new, since all the traditional Crucifixion pictures carry the same message. ${ }^{50}$ Nevertheless, the painting seems to have been destined to instinctive rejection. As Houghton points out evasion was an important aspect of Victorian hypocrisy, ${ }^{51}$ which basically meant that people simply wanted to "shut their eyes to whatever was ugly or unpleasant and pretended it didn't exist." ${ }^{\text {"2 }}$ Hunt's picture discomfited many of its Victorian spectators. Rossetti's comment, made when he first saw The Scapegoat, shows his clear insight into the situation; he said that The Scapegoat was "a grand thing, but not for the public." ${ }^{53}$ Ruskin, on the other hand, proved to be a typical Victorian in this sense. Already 1846, in the second volume of Modern Painters, he had definitely rejected all pictorial presentations of bodily pain regarding it as morally erroneous. ${ }^{54}$ So he was obviously not pleased by what he saw in Hunt's canvas. After the picture's first display at Royal Academy he wrote that:

... the mind of the artist has been so excited by the circumstance of the scene, that, like a youth expressing his earnest feelings in feeble verse ..., in his honest desire to paint a scapegoat, he has forgotten to ask himself first, whether he could paint a goat at all. ${ }^{55}$

Whether Ruskin, who had probably never seen a dying Middle Eastern goat, was right or just tried to give justification for his instinctive detestation of such an

\footnotetext{
${ }^{49}$ As in many things in connection with The Scapegoat there is a disagreement concerning the sentimental appeal of the painting. While Landow, for example, says that "Hunt has given the animal an almost human expression, which strikes one as ludicrously sentimental rather than deeply moving" (pp. 107f), Hilton claims that "The Scapegoat totally fails to make use of the revolution effected by Edwin Landseer ... through which animals could be made to represent human emotions" (p. 110).

${ }^{5}$ Had Hunt painted a "Crucifixion" it probably would have been more easily acceptable to the public, since that image was so conventional that nobody would have felt offended. But Hunt always wanted to avoid conventionalism, as it is also shown by his unique version of the crucufixion theme, The Shadow of Death, painted between 1870-73.

${ }^{51}$ Houghton p. 395.

${ }^{52}$ Houghton 395.

${ }^{53}$ Letter to William Allingham in 1856. Quoted in Landow p. 108.

${ }^{54}$ Ruskin, Modern Painters, vol. 2, pp. 279.80.

55 Andrea Rose, The Pre-Raphaelites (Oxford: Phaidon Press, 1981) p. 66.
} 
awful, tortured creature is hard to tell. Nevertheless, Hunt was as firm as ever in his determination to adhere to realistic presentation and tried to capture the agony of the goat as perfectly as he could. So much so that, always working after real life models, he bought a goat in Usdam and took it to the proper location, where the poor animal had to perish on the altar of high art being starved to death while 'posing' on the infertile shores of the Dead Sea.

Despite the shocking novelty of the image, it seems, it caused no difficulty for the public to understand its symbolic references. As usual, Hunt provided help by placing biblical quotations as well as other referential signs on the frame. On the upper panel the prophecy of Isaiah can be read: "Surely he hath borne our griefs, and carried our sorrows, yet we did esteem him stricken, smitten of God and afflicted" (53:4). On the lower part of the frame a passage from Leviticus is quoted: "And the Goat shall bear upon him all their iniquities unto a land not inhabited" (16:22). The first citation and its reference to Christ's passion were easily understood by the viewers, who knew it, if not directly from Isaiah then from the text of Handel's Messiah, which was a highly popular piece at the time. ${ }^{56}$ This first reference together with the second quote made the painting's central type easy to grasp.

In the symbolism of the picture Hunt basically relied on the descriptions of the Day of Atonement ritual as it is found in the Bible, the Talmud, and J. Lightfoot's The Temple Service as it Stood in the Dayes of our Saviour (1649). According to the Hebraic custom two goats were selected as penitential symbols of human sin on the Day of Atonement, one of which was sacrificed on the altar, while the other was first abused by being beaten, kicked and spat upon, then sent into the wilderness to perish slowly. Thus it carried away the sins of man, which were transferred to the goat beforehand by "lay[ing] both ... hands upon the head of the live goat, and confess[ing] over him the iniquities of the children of Israel, and all their transgressions in all their sins" (Leviticus 16:21). It was also part of the tradition that a red fillet was bound about the horns of the goat, and as the

\footnotetext{
${ }^{56}$ See the letter of Lowell Mason, in Sept. 1852: "Whatever may be the reason, the fact is certain, that in England the Messiah is vastly more popular than any other oratorio. The best judges of music, professors and amateurs, the learned and the unlearned, the noble and the ignoble, the great and the little, those who ride in proud carriages, with servants liveried with buff and scarlet, and those who walk through the rain with cotton umbrella, the old and grave, the young and gay, those who love music, and those who do not know whether they have any love for it or not; - all do homage to this mighty production of Handel." Quoted in J. M. Golby, ed., Culture and Society in Britain 1850-1890 (Oxford: Oxford University Press, 1986) p. 167.
} 
sign of God's acceptance of man's offering and His remission of sins the colour of the fillet turned from red to pure white. Accordingly, Hunt's picture shows the goat with a red fillet around his horns, indicating that redemption has not yet come.

The painting perfectly renders the stifling heat and heavy, oppressive air of the hot summer eve in Usdam, as the Atonement rituals were traditionally performed in September or in October. Total devastation rules the land, where all that lives is doomed to perish, as it is shown by the eerie skeleton of a camel in the background. As he says in one of his letters, ${ }^{57}$ Hunt himself wanted the sense of despair to suppress the sense of hope, that is why he made certain changes between the first, smaller version and the final, bigger one. ${ }^{58}$ The first version suggests far more optimism presenting a magnificent rainbow spanning over the desolate land, the rainbow traditionally referring to God's mercy and a renewed covenant on the basis of Gen. 9:8-17. Finding it too dominant and too optimistic, Hunt omitted the rainbow from the second version, and he also changed the colour of the goat. Originally he wished to paint a black goat, which was more common, seeing it as the personification of Azazeel, the evil demon (Lev. $16: 8,20,26)$, but later he opted for the rarer white one in order to emphasise the purity, the sinless nature of the animal, and therefore strengthening its symbolic power as a type of the Saviour.

There are, however, faint but obvious references to future redemption, which somewhat sooth the overall despair of the scene. An olive branch shown in the lower left corner represents not just life as a plant but also recalls the story of Noah in Genesis suggesting the coming end of the devastation. The reflection of the full moon on the water shown in the upper left corner appears as a halo round the horns of a scull in the water, which may refer to the other goat already sacrificed in the temple and accepted as an offering. The decorations on the frame also try to counterbalance the overwhelming eerie atmosphere of the picture. The olive branch is shown again on the left frame, and facing it on the right a fivepetalled rose can be seen, a conventional symbol of the stigmata, out of which four trees grow in the direction of the four cardinal points, together probably standing for the renewal of life acquired through the Passion and sacrifice of Christ. On the horizontal frames a group of seven stars and a seven-branched

\footnotetext{
${ }^{57}$ Letter to Agnew in 1906, quoted in The Pre-Raphaelites p. 154.

${ }^{58}$ The first, smaller version was started in 1854 , but actually finished only in 1858 , later than the second, bigger one, which was begun on 17 November 1854 and completed in early June in 1855 .
} 
candlestick are shown referring to the seven churches of Christ and their angels (Rev. 1:20) as they appear in the hands of the Saviour at the Last Judgement, who finally makes them triumphant.

However, these tiny details did not relieve the painting of its terror. And even if it was not taken with widespread enthusiasm by the public, Rossetti's appreciation was echoed by other artist friends who regarded The Scapegoat as something special, as something matchless in the history of religious art. Charles Collins expressed his enthusiasm writing to Hunt:

I was especially struck with the noble idea of the Scapegoat. It is a glorious subject full of wild terror and (much more) one of the strongest and most unmistakable types of Him who bore our sins and was wounded for our transgressions and as that it becomes a theme of the utmost and most touching interest and importance. I envy you the subject, only glad that it has got into better hands than mine. ${ }^{59}$

And another colleague, Ford Madox Brown wrote that:

... Hunt's Scapegoat requires to be seen to be believed in. Only then can it be understood how, by the might of genius, out of an old goat, and some saline encrustations, can be made one of the most tragic and impressive works in the annals of art. ${ }^{60}$

BENEATH THE SURFACE:

HUNT'S FLEXIBLE APPROACH

TO RELIGION

While staying in the Holy Land and working on The Finding and The Scapegoat, Hunt became acquainted and then made friends with a unique person of prophetic nature, a Zionist and early advocate of world peace; Henry Wentworth Monk. At that time Monk was absorbed in his studies of Revelation, and his thoughts and ideas as well as his individual approach to the Bible made a strong impression on Hunt. ${ }^{61}$

\footnotetext{
59 Landow p. 109.

60 Wood p. 44.

${ }^{61}$ As Hunt wrote: "His [Monk's] knowledge of history, and his enthusiasm for the progressive thought stored in the Bible, made him of special interest to $\mathrm{me}^{n}$ (Andrea Rose, Pre-Raphaelite Portraits. [Oxford: The Oxford Illustrated Press, 1981. p. 56]). And also: "He is certainly a man of
} 
Monk was born in Canada, and was originally trained for the Church of England, but during a serious illness, when he was in a trance, he experienced a revelatory vision of God, which entirely changed his view of religion. From that time on he firmly rejected all forms of traditional religious teaching, and started studying the Bible as if it were a record of similar revelations to the one he himself had experienced in his trance. In his studies he relied solely on the text of the Scriptures disregarding all commentaries, and he came to the final conclusion that the promised millennium was imminent. Besides his biblical studies he also stood up for the foundation of an independent Jewish state in the Holy Land regarding its establishment as his own appointed mission.

Though Hunt could not accept many of Monk's prophetic ideas, he revered his friend's genuineness and vast knowledge, and found Monk's missionary zeal akin to his own belief in the priestly nature of art and his own divine mission as an artist. So together with Ruskin he helped Monk to have the fruit of his hard work, an individual interpretation of the Revelation ${ }^{62}$ published in 1858. During the time Monk spent in London preparing the publication, Hunt painted a portrait of him, which was to accompany the written work in its propagation of Monk's ideas.

Accordingly, all the details in the picture bear significant references to Monk's views. He is shown in a priestly, gold and brown eastern robe, which refers to his errand to work for the establishment of a Jewish state, and which is decorated with golden stars, emblems of heavenly brightness. ${ }^{63}$ His missionary zeal and strong determination are suggested by his undeviating expression. The long hair and beard, which were grown under the vow of not cutting them until the kingdom of Heaven was established on Earth, make his appearance that of a prophet. He holds in his right hand a copy of the Greek New Testament open at the last pages: at the Revelation, and in his left he has a sealed copy of The Times referring to the seven seals mentioned in Revelation and suggesting that the time had finally come for them to be broken (Rev. 5). The green glass window, which is made of square panels with bubbles in the middle, and which provides the background to the painting, also refers to Monk's pamphlet. It is there to recall

intellect and with the clearest exposition of the Bible mysteries I have ever heard" (The PreRaphaelites p. 181).

${ }^{62}$ A Simple Interpretation of the Revelation (1858)

${ }^{63}$ In the case of these allusions Hunt relied on Pugin's Glossary of Ecclesiastical Ornament and Costumes (1844). 
the sea of glass described in Revelation (4:6, 15:2), which can be identified with the water above the firmament mentioned in Genesis (1:6-8); in both cases referring to Heaven itself. It is also important that Hunt painted the glass of the window opaque, for it suggests that the heavenly world could not yet be clearly seen, since the millennium had not yet come. As is said in the Bible:

For we know in part, and we prophesy in part,

But when that which is perfect is come, then that which is in part shall be done away. ...

For now we see through a glass, darkly; but then face to face: now I know in part, but then shall I know even as also I am known(1Cor. 9:10,12).

Monk's portrait was exhibited at the Royal Academy in 1860, and, as the sitter's religious views were not familiar to the public, its symbolism was basically unnoticed. In the case of this painting, luckily for Hunt, no one suspected religious propaganda. Monk's pamphlet, just like Hunt's painting, passed unmarked, leaving the sitter and his views in obscurity. Had Hunt's openmindedness and support for such an independent religious presentation been known, it probably would not have remained without comment and criticism.

The general unconcern for Monk's pamphlet at the time of fervent religious debates may seem peculiar. Essays and Reviews, a collection of seven essays concerned with Bible-interpretation ${ }^{64}$ set off an excited stir in the clerical world, despite the fact that the liberal views that some of the essays propagated were not entirely new. In general the volume which was promoted by Frederick Temple, first principle of Trinity College, and Benjamin Jowett, Master of Balliol, was intended to "encourage free and honest discussions of Biblical questions." Owen Chadwick's opinion the main reason for the agitation that followed the publication of Essays and Reviews in 1860 was not so much its content, but rather the fact that the essays were written by eminent members of the Church of England, ${ }^{66}$ and "if laymen had written it," writes Chadwick, "it would have fallen dead from the press." ${ }^{67}$ Monk was, on the contrary, an isolated, eccentric prophet,

\footnotetext{
${ }^{64}$ Just like Monk, one of the essayist, Benjamin Jowett also stood for studying the Bible independently from all traditional interpretations.

${ }^{65}$ Chadwick vol. 2, p. 75.

${ }^{66}$ As has already been mentioned, the only layman among the authors was C. W. Goodwin, the others, Temple, Jowett, Rowland Williams, H. B. Wilson, Mark Pattison, and Professor Baden Powell held important clerical posts.

${ }^{67}$ Chadwick vol. 2, p. 78.
} 
who had nothing to do with the institution of the established church, and who even spent most of his life far away from England. Thus the publication of his individual ideas was seen as no threat to the Anglican Church.

\section{PICTORIAL HISTORICISM: THE SHADOW OF DEATH}

Parallel to the desire to reconsider some aspects of the traditional interpretation of the Bible, there was a popular demand for a historically reliable account of the life of Christ. As has already been mentioned, the first biography of Christ written in this spirit was Strauss' Leben Jesu in 1835, but the real flood only followed in the 1860s. As Owen Chadwick points out, ${ }^{68}$ the trend was significantly boosted as travelling became much easier than it had been before, which encouraged ever more people to explore distant and exotic countries. Given its sacred appeal, the Holy Land had always been a popular destination, and those who could afford the journey obtained a real knowledge of the land and the people of which so far they had only remote and obscure ideas. And as 19th-century Palestine became familiar through personal experiences and written or pictorial accounts, so did the Palestine of the first century start to lose its mysticism.

A lively, though somewhat idealised image of Palestine appeared in Ernest Renan's famous biography of Christ, Vie de Jesus. It was first published in 1863, and though the English translation was not as highly popular as its original French edition, it was widely read, and it also stimulated English writers to follow suit. The first account of Christ's life from an English author was published quite soon, in 1865 . The book, Ecce Homo was brought out anonymously, ${ }^{69}$ which probably contributed to the fact that it soon became a central topic of conversation. Typically of general interest, the peak in its sale came after Lord Shaftesbury's public remark describing Ecce Homo as "the most pestilential book ever vomited ... from the jaws of hell." ${ }^{, 30}$ Nonetheless, the book was very much in agreement with the general concerns of most churchmen and intellectuals, since it drew attention to the importance of Christian morality. The next biography of Christ, Sir Richard Hanson's The Jesus of History was issued in 1869, and it was followed within just five years by F. W. Farrar's Life of Christ. Farrar's work became far the most popular among all the biographies in England. Apart from

\footnotetext{
${ }^{68}$ Chadwick vol. 2, p. 62.

${ }^{69}$ The author later turned out to be J.R. Seeley, professor of Latin at University College, London.

${ }^{70}$ Chadwick vol. 2, p. 65.
} 
these complete biographies, several pamphlets, studies, and articles were published on the same subject from such prominent authors as Samuel Hinds, former Bishop of Norwich, C. J. Ellicott, Bishop of Gloucester and Bristol, and Arrchbishop Thomson of York.

With his next painting, Hunt made a pictorial contribution to the current interest in the history of Christ's life. The idea of The Shadow of Death (1870-73) was suggested to the artist by his reading of Renan's book, in which he saw the manifestation of a similar desire for realistic presentation in writing to his own in painting. As he wrote in one of his letters:

... with my particular picture [The Shadow of Death] and old religious
priest teaching I see nothing at all in common, and I should think that so
far from any ecclesiological school being pleased with it that it is more
fitted by itself for the Renan class of thinkers who have been studying
the life of Christ as one particular branch of history - ... my picture is
strictly - as the Temple picture was - bistoric with not a single fact of
any kind in it of a supernatural nature, and in this I contend it is
different for all previous work in religious art.

In its conscientious realism, The Shadow of Death is obviously a successor of the previous The Finding. There is, however, an important novel element in its conception. So far Hunt relied on the prefigurative symbolism of the Bible itself in his paintings, but here, for the first time, he himself created a type, which was entirely visual, which did not and could not have a written equivalent. Christ is depicted in the painting as a carpenter, who is stretching out his exhausted body after a long day's hard work. With his extended arms his body constitutes a cruciform, the shadow of which is reflected on the wall behind, cast at a wooden rack of tools. The visual images of Christ and his shadow become the prefigurative symbols of the Crucifixion.

To show the Saviour as a toiling carpenter was in itself a quite novel thing. Christ was sometimes shown as a young boy assisting St Joseph, who is known to have been a carpenter, but Christ himself is usually not associated with the craft, despite the fact that according to a brief reference in the Bible (Mark 6:3) he had worked as a carpenter until he started his missionary work at the age of about thirty. The timing for Christ's presentation as a labourer was ideal. Showing Christ as a working man, taking on ordinary, manly tasks was a

${ }^{71}$ Quoted in The Pre-Raphaelites p. 221. 
conception which very pertinently reflected upon the dominant issues concerning contemporary spectators. The citation inscribed on the frame was again carefully chosen by Hunt to suit his painting and support the message it carried. It is from the Epistle of St Paul to the Philippians, in which the apostle exhorts his readers to follow Christ's example in love, unity, and humility. The inscribed lines emphasise Christ's own humiliation as the servant of the Lord, taking on a human form and unquestioning obedience:

...he made himself of no reputation, and took upon him the form of a servant, and was made in likeness of men:

And being found in fashion as a man, he humbled himself, and became obedient unto death, even the death of the cross. (Phi. 2:7-8)

Just like the painting itself these lines emphasise Christ's likeness to man and not his superiority, just as it was intended by Christ's ardent biographers. In addition, the painting displays an explicit reference to the value of labour by associating it with the Saviour. As has already been mentioned in connection with The Finding, work was a key notion for the Victorians; but whereas The Finding concentrated on work as a mission or duty, The Shadow of Death focuses on its physical nature. The interpretation of work in this sense was more ambiguous, since Hunt had to reconcile the 19th-century evaluation of labour with the traditional biblical view of it which in itself was equivocal.

Manual labour was held in unusually high esteem in the second half of the 19th century. Generally the Broad Church party was known for its respect for the labourer and his hard work, especially because of the ideas and activities of two of its leading personalities, Thomas Arnold and Frederick Denison Maurice. But apart from them, Carlyle was also a well-known advocate of the ennobling effect of both mental and physical work, and John Ruskin as well as William Morris thought likewise. Ruskin, for example, as Slade Professor at Oxford University took his students to build roads finding it a useful complementary to their intellectual education. Morris, in his utopian novel News from Nowhere and in his articles like How We Live and how We Might Live and Useful Work Versus Useless Toil, often confirmed his belief in the utility as well as the joy of creative and productive physical work.

The respect for manual labour often also featured in contemporary painting. Ford Madox Brown's Work (1865), which was conceived under the influence of Carlyle's writings, is known as the pictorial glorification of man's power to do useful work. William Bell Scott's Iron and Coal (1861), Millais's The 
Resque (1855), and John Brett's The Stonebreaker (1858) show similar pride and respect. Even the exhausted, effete, haggard workman was sometimes seen as respectable, as it is shown by Henry Wallis's The Stonebreaker (1858). Wallis, quite typically, quoted Carlyle in the exhibition catalogue:

Venerable to me is the hard Hand; crooked, coarse; ... indefeasibly royal, as of the Sceptre of this Planet. Venerable too is the rugged face, all weather-tanned, besoiled, with its rude intelligence; for it is the face of a Man living manlike. Oh, but the more venerable for thy rudeness, and even because we must pity as well as love thee! Hardly entreated Brother! For us was thy back so bent, for us were thy strait limbs and fingers so deformed: thou wert our conscript, on whom the lot fell, and fighting our battles wert so marred. For in thee lay a good-created form, but it was not to be unfolded; encrusted must it stand with the thick adhesions and defacements of labour, and thy body, like thy soul, was not to know freedom. ${ }^{72}$

Though Carlyle's view was steadily spreading and the presentation of the defacements of labour in connection, for example, with a stonebreaker became acceptible or even respectable, the same thing probably would not have applied to a painting presenting the members of the Holy Family. Thus while Hunt was as accurate as ever in the presentation of the Middle Eastern workshop, he paid attention to show Christ as a strong, muscular young man perfect and healthy not just in soul, but in body alike. When twenty-four years earlier Millais had depicted St Joseph in his Carpenter's Shop he showed a real carpenter with all the bodily deformities caused by his hard work, so, in this sense, his work was more realistic and more audacious than Hunt's The Shadow of Death. No wonder, therefore, that while Millais' work was found appalling, Hunt's picture was greeted with sincere enthusiasm.

Similarly to the 19th-century view of the true worth of labour, the Bible also regards work as a dignifying duty of man. Work is the task devolved on man by God (1Thes, 4:11); it is the condition of his living, as well as the source of his happiness (Psalms 128:1-4). However, hard daily labour is also referred to as a punishment imposed on man after the Fall (Gen. 3:17-19). Its cessation in the evening is, therefore, an obvious relief. The pamphlet ${ }^{73}$ which accompanied the

\footnotetext{
72 From Sartor Resartus, quoted in The Pre-Raphaelites p. 167.

${ }^{73}$ Supposedly written by Hunt himself. Cf. The Pre-Raphaelites p. 221.
} 
painting at the time of its first exhibition in 1873, pointed out both of these aspects of manual labour.

As Christ's daily work ends in the painting with his stretching, so would his work as the envoy of God on earth be accomplished by his crucifixion. Christ's passion and the Crucifixion are recalled by some other symbols. The reeds on the left, for example, refer to the mock sceptre given to Christ's hands, the red fillet carries all the references explained in connection with The Scapegoat, and here it also recalls the crown of thorns. The shadow of the saw appears as a spear pointing to the shadow image's heart which is represented as a plumb-bob hung on the wooden rack. The pomegranates on the window sill are traditional symbols of the Resurrection. The semi-circular upper section of the window behind Christ appears as a halo around his head, while the star in the middle refers to the prophecy of Balaam (Num. 24:17) and to the star which guided the Magi to the new-born Jesus. The visit of the Magi is also indicated by their gifts, revealed in the open chest on the left.

Mary is shown opening the chest, suddenly noticing the eerie cruciform shadow of her son on the wall; a moment of disturbing foreboding to her. Thus the painting can be seen again as a unique version of the ancient Annunciation theme ${ }^{74}$ where the divine revelation is carried by the vision of the cross, and where not the birth, but the death of Christ is announced. Mary's kneeling position is reminiscent of the traditional Annunciation scenes, but here she is shown with her back to the spectator, which was regarded by contemporary critics as the manifestation of anti-Catholicism. ${ }^{75}$

The Shadow of Death, just like the previous The Finding, was greeted with general approval, and, for obvious reasons, the painting enjoyed an unusual popularity among the working classes. Despite, however, the success of the historical-realistic approach applied by Hunt in this painting, he was still fascinated by religious mysteries, and returned to its presentation in his last religious work, The Triumph of the Innocents (1876-87).

\footnotetext{
${ }^{74}$ Cf. Stephen Adams, The Art of the Pre-Raphaelites (New Jersey: Chartwell Books, 1988) p. 120; Landow p. 121.

${ }^{75}$ Cf. The Pre-Raphaelites p. 223; Adams p. 120.
} 


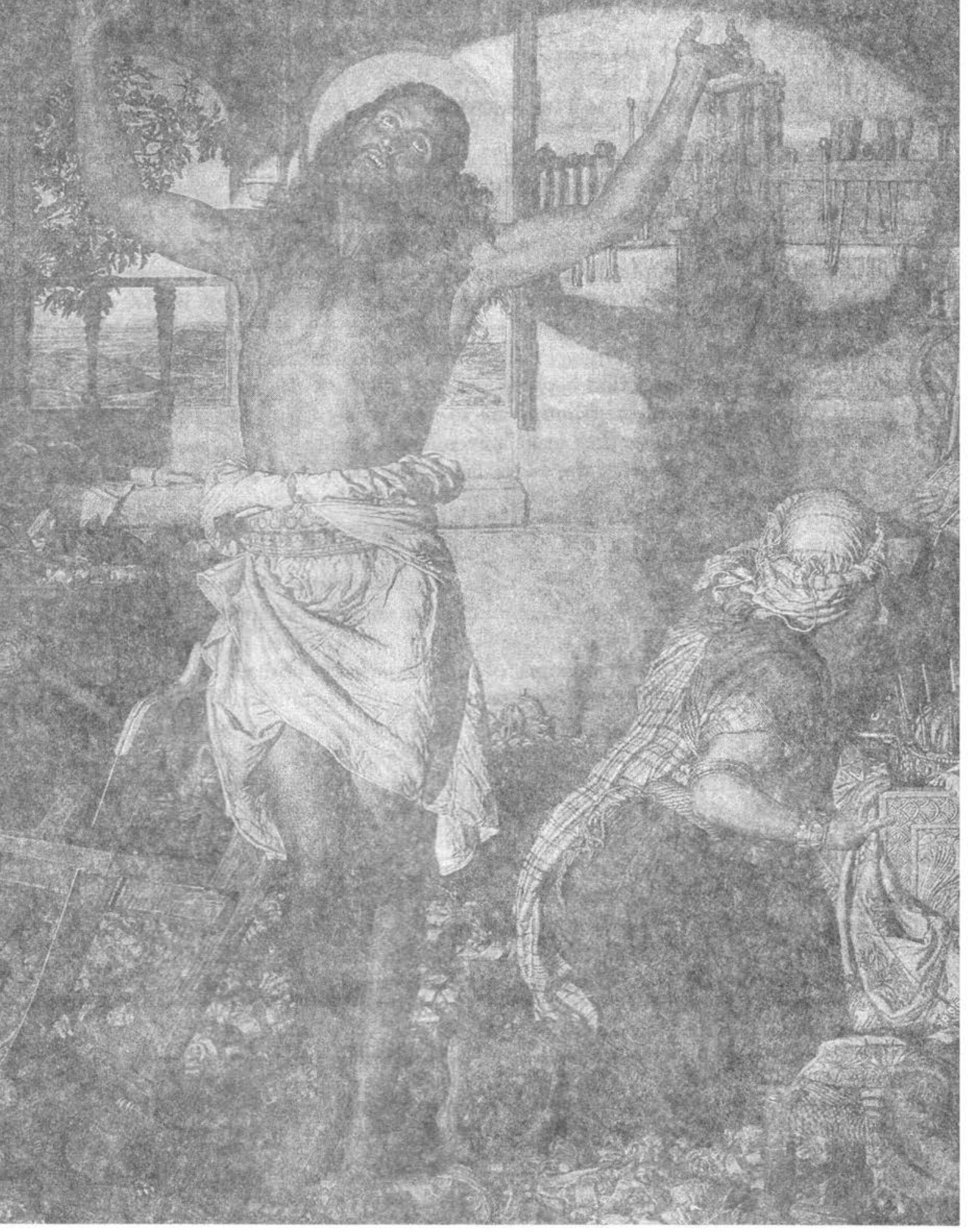




\section{RETURN TO MYSTICISM: THE TRIUMPH OF THE INNOCENTS}

After the relative comprehensibility of The Shadow of Death, The Triumph puzzled even the connoisseurs. The reason for the spectators' bewilderment was manifold. First of all Hunt combined two traditional, originally individual types of biblical presentations; the 'flight into Egypt' theme and that of the 'massacre of the Innocents.' In addition, the supernatural elements employed in this picture are far more unconventional than the ones, for example, in The Light of the World, and while The Light of the World presents an entire vision as it was envisaged in the painter's imagination, The Triumph shows the vision and its seer at the same time, making hardly any distinction between the real and the visionary. Furthermore, many of the symbols of the painting are so individual that instead of extending the meaning of the picture, they make it even more obscure.

The picture presents the Holy Family's escape from Bethlehem under cover of darkness: Mary, holding the infant Christ, is shown sitting on a donkey, which is led forward by St Joseph. So far the image is wholly conventional. It is unusual, however, that the proceeding Holy Family is accompanied by a procession of small children; three babies are even shown hovering in the air above the group on the ground. Each of these children is enveloped in a delicate layer of sacred light, otherwise they look like ordinary human figures. But they are actually spirits, the reincarnations of those children, who had been killed by Herod's troops in Bethlehem. They seem to be visible only to Christ, ${ }^{76}$ who smilingly greets them turning and looking back to them twisting his body in his mother's arms. The fact that Christ catches sight of the otherworldly connects The Triumph with The Finding, though here the revelation is merely seen, and comprehended. Mary seems to be immersed in thought, while Joseph is looking back on the distant town they have fled from.

The children are shown as the first martyrs whose lives were sacrificed for Christ. They carry the attributes of their sacrifice and their subsequent redemption; garlands of flowers and laurel wreaths are around their waists and on their heads. The different plants in the hands of some of them are all biblical ones, each conveying a reference to salvation: the blossoming apple branch traditionally

\footnotetext{
${ }^{76}$ Discussing the painting in one of his letters Hunt mentions that the vision is granted to the Virgin Mary, however, it becomes apparent in neither versions of the painting itself. Mary seems to be deeply immersed in thought, showing no concern for the proceeding spirits. For Hunt's letter see: Landow p. 130.
} 
symbolising immortality, the red rose martyrdom, while the palm stands for the everlasting victory of those who died for Christ. The olive branch means hope and reconciliation, and the wine refers to Christ's blood in the Eucharist. The ripe ears of wheat in Christ's hand may refer to the bread of the Eucharist, but it also recalls a conventional pictorial version of the flight into Egypt theme, which presents in the background a field that is being put under wheat or where the wheat is being harvested. ${ }^{77}$ This type of presentation goes back to the legend according to which on their flight the Holy Family passed a corn field just being sowed, and by the following day, when Herod's men inquired about the family, the wheat was already harvested.

Some of the children are endowed with further allusive marks. The one on the far right, leading the whole group, appears as a priest at the head of a procession. He is the only one who wears a long, brightly coloured dress, reminiscent of priestly robes, and also the only one looking forward and a bit upwards as if following divine guidance. The second child, marching right after him, is pointing a palm branch to the ground in front of the Holy Family, recalling the scene of Christ's entry to Jerusalem, the first stage of his passion and sacrifice. Another little boy in the foreground of the painting is a proper pictorial type of Christ, he is wounded on the chest recalling Christ's spear-wound suffered on the cross, and the pearls of the ruby necklace in his hands suggest the drops of Christ's blood.

The children proceed along and on a strange watery substance, sometimes narrow as a string of ropes, sometimes flat and round as a pool, which turns into shiny bubbles, or, as they were called by Hunt, into 'airy globes ${ }^{, 78}$ when it should cross a real brook. This unearthly surface on which the spirits of the Innocents move on is the stream of eternal life, which is transformed into bubbles since it cannot blend with ordinary water. The two biggest ones of these airy globes present individual pictures within the painting with symbolic references to Creation, the Fall, and the Redemption. Landow gives a detailed description of these visionary globes ${ }^{79}$ relying on Hunt's own 15-page long explanation in the 1885 exhibition catalogue. According to it the biggest bubble shows Jacob's ladder connecting earth and heaven (Gen. 28:12-17), being thus often used as a type of

\footnotetext{
$"$ See, for example, Hans Vereycke: Landscape with the Rest on the Flight into Egypt, or Joachim Patinir: The Rest on the Flight into Egypt.

${ }^{78}$ Quoted in Wood p. 104.

${ }^{79}$ Landow pp. 130-35.
} 
Christ. In the middle of the globe the Tree of Life can be seen, another prefigurative symbol of Christ, which is often identified with the cross. The lion and the lamb, both symbols of Christ (Rev. 5:5-6), one for its power and strength, the other for its purity, are also presented. On the right, above the animals, a procession upon the heavenly ladder can be seen, while on the left a woman is shown as if being driven out from the Garden of Eden. The other, much smaller globe shows a red serpent approaching Christ's heel, recalling how God cursed the serpent after the Fall saying: "I will put enmity between thy seed and her seed; it shall bruise thy head; and thou shalt bruise his heel"(Gen. 3:15). In traditional Christian theology this section is usually interpreted as the Lord's prophecy of Mary's triumph over original sin by giving birth to the Saviour, and of Christ's Passion and Crucifixion.

The inspiration for all these symbols came mostly from the Revelation, possibly also from Monk's interpretation of it. Describing the heavenly Jerusalem the Bible says:

And he showed me a pure river of water of life, clear as crystal, proceeding out of the throne of God and of the Lamb.

In the midst of the street of it, and on either side of the river, was there the tree of life....

And there shall be no more curse: but the throne of God and of the Lamb shall be in it; and his servants shall serve him.

And they shall see his face, and his name shall be in their foreheads.

And there shall be no more night there; and they need no candle, neither light of the sun; for the Lord God giveth them light: and they shall reign for ever and ever.

(Rev. 22:1-2, 3-5)

To connect the bloody act of the massacre of the Innocents with these promising passages at the end of the Bible is highly unusual. The incident has always evoked scenes of torment and brutality; the display of human cruelty and selfishness. In his last religious work Hunt turned the bloodiest subject of religious painting into the celebration of Redemption and immortality.

Ruskin was understandably ecstatic about the painting, declaring that it was "the greatest religious painting of the time." ${ }^{80}$ But his contemporaries were more puzzled than enthusiastic. No one doubted the picture's merits and the painter's creativity in producing once more something new and revolutionary,

${ }^{80}$ Quoted in Frederick Harrison, John Ruskin (London: MacMillan and Co., 1907) p. 80; and Wood p. 104. 
but most viewers were disturbed by "the strange mixture of real and unreal" the painting. F. G. Stephens, for example, found it "self-contradictory and puzzling," regarding The Triumph as a "noble failure." 82 In the Edinburgh Magazine a contemporary critic expressed the same when he wrote: "We honour the artist's aspiration, yet the attempt to render the minds intangible imaginings palpable to sense, is proved once more beyond the range of pictorial art." ${ }^{83}$ Present-day criticism of the painting is also divided: to Graham Hough it is "original and beautiful," while Stephen Adams regards it as "a profoundly idiosyncratic and unlovely flight of fancy," $" 85$ and Christopher Wood as artistically not satisfying. ${ }^{86}$

Talking of Hunt's religious works in general, Wood claims that these pictures

... are symbols of Victorian faith; [which] to our sceptical, twentiethcentury eyes ... seem too laboured, too sentimental and too evocative of the very kind of Victorian religiosity and humbug we have deliberately rebelled against. ${ }^{87}$

Nevertheless, all that these paintings reflect and manifest was, beyond any doubt, genuinely thought and felt by the painter, even if by today they definitely seem to be outdated and typically Victorian. But, at the same time, Hunt's works also reveal that he was unusually open-minded in his approach to religious issues, giving attention to Tractarian, Evangelical and independent views alike, and in this sense he was unlike most of his contemporaries.

Despite the fact that his faith deeply influenced his art, it is, as Landow points out, "difficult to define precisely the nature of that belief." 88 But, as he concludes, "Hunt's emphasis on strict morality, personal conversion, and typology all [suggest that] he shared more major points of belief with the

\footnotetext{
${ }^{81}$ In Art of England (1883), quoted in Harrison p. 143.

${ }^{82}$ Quoted in Wood p. 104.

${ }^{83}$ In $\mathrm{Mr}$ Holman Hunt: His Work and Career. In Blackwood's Edinburgh Magazine, 1886. In http://www.stg.brown.edu/projects/hypertext/landow/Hunt/Triumph.

${ }^{84}$ Graham Hough, The Last Romantics (London: Gerald Duckworth, 1949) p. 66.

${ }^{85}$ Adams p. 120.

${ }^{86}$ Wood p. 106.

${ }^{87}$ Wood p. 106.

${ }^{88}$ In William Holman Hunt's Religious Belief in http://www'stg.brown.edu/projects/hypertxt/ landow/Hunt.
} 
Evangelicals than with other parties. ${ }^{89}$ Nevertheless, the fact that, despite his prophetic vocation, he never openly took sides suggests that he did not think of himself belonging to any. Hunt seems to have agreed with Ruskin that:

... violent combativeness for particular sects, as Evangelical, Roman Catholic, High Church, Broad Church, - or the like, is merely a form of party egotism, and a defiance of Christ, not confession of Him. ${ }^{90}$

${ }^{89}$ In William Holman Hunt's Religious Belief in http://www.stg.brown.edu/projects/hypertxt/ landow/Hunt.

${ }^{00}$ John Ruskin, Fors Clavigera (London: George Allen, 1896) vol. 1, p. 296. 